\title{
Pengujian Tingkat Efisiensi Alat Pengering Multi Komoditas Tipe Udara Hembus Berbahan Bakar Biomasa
}

\author{
Irwan Wunarlan \\ Jurusan Teknik Industri, Fakultas Teknik, Universitas Negeri Gorontalo \\ email : irwan.wunarlan@ung.ac.id
}

\begin{abstract}
Abstrak
Salah satu alat teknologi tepat guna yang saat ini dikembangkan di Laboratotium Teknik Industri FT UNG yakni Alat Pengering Multi Komoditas Tipe Udara Hembus berbahan bakar biomasa (Tipe UHB). Teknologi tepat guna ini sangat dibutuhkan oleh masyarakat Gorontalo yang berprofesi sebagai petani dan nelayan. Penelitian ini ditujukan untuk menguji tingkat efisiensi mesin pengering multi komoditas tipe UHB dengan menggunakan metode uji kinerja pengering. Hasil pengujian ini memyimpulnya bahwa (1) APMK tipe UHB memiliki performance yang baik bila ditinjau dari proses pengeringannya, alat pengering ini dapat menurunkan kadar air dari suatu produk hingga 33,53 \% dengan laju pengeringan mencapai 1,87 kg udara/m2.jam namun memiliki tingkat effisiensi yang rendah yakni sebesar 13,44\%, dan (2) Ada dua parameter yang unggul dari performance APMK tipe UHB jika dibandingkan dengan alat pengering Tipe Circulation Dryer yakni berat muatan perluasan pengering dan kecepatan udara.
\end{abstract}

Kata Kunci: teknologi tepat guna, alat pengering, performance, efisiensi

\begin{abstract}
One of the appropriate technology tools currently developed in the Industrial Engineering Laboratory of the UNG FT is the Multi-Commodity Type Biomass Blowing Air Dryer (UHB Type). This appropriate technology is needed by Gorontalo people who work as farmers and fishermen. This study aims to test the level of efficiency of multi-commodity drying machine type UHB using the dryer performance test method. The results of this test conclude that (1) UHB type APMK has a good performance when viewed from the drying process. This dryer can reduce the water content of a product to $33.53 \%$ with a drying rate reaching $1.87 \mathrm{~kg}$ air / $\mathrm{m} 2$.hour but has a low level of efficiency $(\eta)$ of $13.44 \%$, and (2) There are two parameters that are superior to the performance of the UHB type APMK when compared to Circulation Dryer Type dryer such as the weight of the dryer expansion load and air speed.
\end{abstract}

Keywords: village technology, drying tool, performance, efficiency

\section{Pendahuluan}

Sebagai negara kepulauan, Indonesia memiliki ribuan pulau dan wilayah laut yang sangat luas dengan potensi sumber daya pesisir serta lautan yang melimpah menjadi aset untuk mendukung pembangunan daerah dan nasional (Nugroho dan Dahuri, 2012). Provinsi Gorontalo sebagai salah satu provinsi di wilayah Indonesia memiliki berbagai potensi sumber daya baik sumber daya pertanian khususnya tanaman pangan dan perkebunan serta sumber daya perikanan. Pertanian adalah penggerak perubahan transformasional yang telah terbukti dan dengan menerapkan sains dan teknologi, komunitas dapat meningkatkannya penghidupan, dengan demikian, membantu 
meningkatkan ekonomi pertumbuhan negara (Othman, et all, 2016). Masyarakat Gorontalo yang bermukim diwilayah pesisir pantai dan bermata pencaharian sebagai nelayan berjumlah $7.733 \mathrm{KK}$ dengan jumlah tangkapan ikan sebanyak 118.401 ton per tahun (BPS, 2017). Sementara masyarakat Gorontalo yang bermukim diwilayah pedalaman (hiterland) atau pedesaan (rural) dan mengantungkan penghidupan pada sektor pertanian tanaman pangan (jagung) serta perkebunan (kelapa) berjumlah 32.516 KK dengan total produksi sebanyak 719.787 ton (jagung) dan 66.793 ton (kelapa). Hasil produksi tanaman pangan (jagung), perkebunan (kelapa) dan perikanan (ikan) yang dikonsumsi serta dijual berjumlah \pm 75 persen sehingga terdapat sisa komoditas yang tidak dikonsumsi dan tidak terjual sebanyak \pm 25 persen. Produk segar berbagai komoditas pertanian dan perikanan ini harus diawet melalui penurunan kadar air untuk mencegah pertumbuhan mikroba yang dapat memperburuk kualitas produk segar. Mikroba tidak efektif jika ketika kadar air suatu produk di bawah 10\% (Ehiem, Irtwange and Obetta, 2009). Oleh karena itu, petani dan nelayan membutuhkan suatu alat tepat guna (village technology) untuk mengawetkan komoditas tersebut sehingga petani dan nelayan tidak mengalami kerugian. Salah satu alat teknologi tepat guna yang saat ini dikembangkan di Laboratotium Teknik Industri FT UNG yakni Mesin Pengering Multi Komoditas Tipe Udara Hembus berbahan bakar biomasa (Tipe UHB). Teknologi tepat guna ini sangat dibutuhkan oleh masyarakat Gorontalo yang berprofesi sebagai petani dan nelayan. Penelitian ini ditujukan untuk menguji tingkat efisiensi mesin pengering multi komoditas tipe UHB dengan menggunakan metode uji kinerja pengering (Junaidi, Bukhari dan Maimuzar, 2011). Adapun komoditas yang digunakan adalah ikan sebagai bahan uji coba dalam mengukur tingkat efisiensi mesin pengering multi komoditas tipe UHB. Pemilihan komoditas ikan sebagai bahan uji coba disebabkan ikan merupakan bahan makanan yang banyak dikonsumsi masyarakat baik di dalam maupun di luar negeri. Bahan makanan ini banyak disukai karena memberi manfaat untuk kesehatan tubuh yaitu mempunyai kandungan protein yang tinggi dan kandungan lemak yang lebih rendah dibanding sumber protein hewani lain. Namun, ikan cepat membusuk karena adanya bakteri dan enzym jika dibiarkan begitu saja tanpa proses pengawetan (Wolok dan Wunarlan, 2012).

Hasil tangkapan ikan yang melimpah dan tidak terjual habis serta proses penanganan yang tidak tepat akan berdampak kerugian bagi para nelayan. Para nelayan selama ini melakukan proses pengawetan dan pengeringan ikan secara tradisional dengan cara digarami atau dijemur. Cara ini terkadang mengalami beberapa kendala cuaca seperti hujan, terpaan debu menyebabkan produk (Al-Kayiem dan Yunus, 2013) yang dihasilkan kurang higenis, butuh waktu yang cukup lama dalam proses 
pengeringan dan bobot ikan yang berkurang drastis disebabkan beberapa bagian ikan habis dimakan oleh burung ataupun kucing. Guna mengatasi permasalah yang dihadapi oleh para nelayan maka diperlukan suatu teknologi tepat guna (village technology) berupa alat pengering yang dapat difungsikan setiap saat.

Salah satu upaya pengawetan ikan adalah pengeringan. Pengeringan merupakan proses pengurangan kadar air bahan sampai mencapai kadar air tertentu atau dapat dikatakan bahwa proses pengeringan dilakukan untuk menghilangkan kadar air dari produk (Nindhi and Verma, 2016) sehingga dapat menghambat laju kerusakan bahan atau produk akibat aktivitas biologis dan kimia. Parameter-parameter yang mempengaruhi pengeringan antara lain waktu pengeringan, suhu, kelembaban udara, laju aliran udara, kadar air awal bahan dan kadar air bahan kering. Salah satu upaya dalam menyeragamkan kadar air akhir dan waktu pengeringan pada setiap produk adalah meresirkulasi produk tersebut sehingga terjadi penerimaan panas pada produk lebih merata. Dasar proses pengeringan adalah terjadinya penguapan air bahan ke udara karena perbedaan kandungan uap air antara udara dengan bahan yang dikeringkan. Agar suatu bahan dapat menjadi kering, maka udara harus memiliki kandungan uap air atau kelembaban nisbi yang lebih rendah dari bahan yang akan dikeringkan (Irfan, 2008). Kandungan air pada ikan asap menurut SNI 2725, I-2009 yakni 60\% (BSNI, 2009) dan kandungan air ikan kering yakni 10,27 \% (Maulana, 2010).

Jenis-jenis pengeringan berdasarkan karakteristik umum dari beberapa pengering konvensional dibagi atas 8 bagian, yaitu (Sitepu dan Purba, 2013) : (a) baki atau wadah, (b) rotary, (c) flash. (d) spray. (e) fluidized bed, (f) vacum. (g) membekukan dan (h) batch dryer. Ada beberapa faktor yang perlu diperhatikan untuk memperoleh kecepatan pengeringan yang maksimum, yaitu (Yani, dkk, 2009; Sitepu dan Purba, 2013) : (a) Luas Permukaan Bahan, (b) Suhu: $40^{\circ} \mathrm{C}-50^{\circ} \mathrm{C}$, (c) Kecepatan Udara: 1,5-2,0 m/s, (d) Kelembaban Udara (RH): , (e) Tekanan Atmosfir Dan Vakum dan (f) Waktu.

Keuntungan dari proses pengeringan adalah Sitepu (2012) : (1) Bahan menjadi lebih tahan lama disimpan, (2) Volume bahan berkurang, (3) Mempermudah proses transportasi dan (4) Menurunkan biaya produksi. Disamping itu, alat pengering dapat menurunkan bahan atau komoditas yang akan dikeringkan lebih cepat dari penjemuran tradisional (Silvia dan Yuwana, 2012) sehingga bahan atau komoditas menjadi lebih awet.

Pengawetan bahan pangan adalah tindakan mempertahankan karakteristik bahan tersebut seperti keadaan awalnya dalam waktu simpan sepanjang mungkin. Faktorfaktor penyebab kerusakan bahan adalah (Witono, dkk, 2013) yakni : (a) Pertumbuhan dan aktivitas mikrobiologi, (b) Aktivitas enzim, (c) Faktor lingkungan dan (d) Waktu. 
Menurut Witono, dkk (2013) mengatakan bahwa metoda pengawetan pangan pada dasarnya adalah mengurangi faktor-faktor yang menyebabkan kerusakan tersebut antara lain dengan :

1. Inhibisi, yaitu dengan memperlambat atau menghambat kerusakan makanan akibat reaksi kimia dan pertumbuhan mikroba. Inhibisi dilakukan melalui kontrol lingkungan, kontrol temperatur, kontrol water activity, maupun kontrol $\mathrm{pH}$.

2. Inaktivasi, yaitu menonaktifkan bakteri, khamir, jamur, dan enzim secara langsung. Inaktivasi dilakukan dengan menggunakan energi panas (pasteurisasi, sterilisasi, memasak, menggoreng), tekanan tinggi, ultrasonik, energi listrik, radiasi/medan magnet.

3. Menghindari rekontaminasi (secara tidak langsung) melalui pengemasan dan manajemen kualitas yang benar.

\section{Metode}

\section{Peralatan Pengujian}

Pengujian tingkat efisiensi alat pengering multi komoditas tipe udara hembus berbahan bakar tempurung kelapa dilakukan di Laboratorium Teknik Industri FT Universitas Negeri Gorontalo. Alat pengering ini merupakan rakitan para mahasiswa yang perlu diuji kehandalannya. Metode pengujian kehandalan alat pengering ini menggunakan metode eksperimental dengan pengujian sebanyak empat kali dan dua kali pengulangan. Adapun sketsa alat pengering multi komoditas tipe UHB nampak seperti pada Gambar 1 di bawah ini.

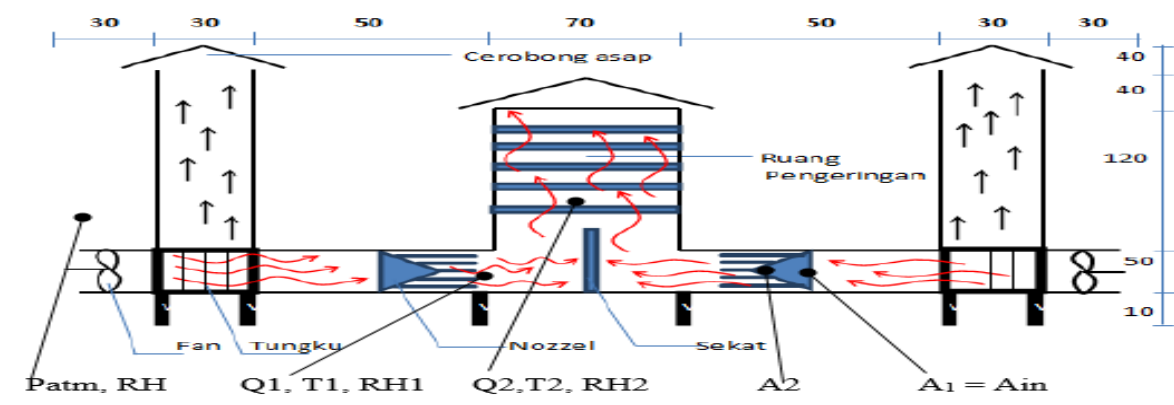

Gambar 1. Alat pengering mekanik multi komoditas tipe udara hembus (satuan $\mathrm{cm}$ )

\section{Bahan dan Alat}

\subsection{Bahan}

Bahan yang digunakan dalam perancangan dan percobaan terdiri atas :

a. Konstruksi alat pengering mekanik multi komoditas menggunakan : (1) Konstruksi utama besi siku berdimensi $3 \times 3 \mathrm{~cm}$; (2) Body konstruksi menggunakan material aluminium plat dengan ketebalan $10 \mathrm{~mm}$; (3) Wadah komoditas menggunakan 
kombinasi besi dengan diameter $6 \mathrm{~mm}$ dan seng plat, dan (4) Kaca dengan ketebalan $5 \mathrm{~mm}$.

b. Komoditas yang diuji menggunakan ikan pelagis (ikan cakalang) : 30,92 kg.

c. Sumber panas berasal dari pembakaran batok kelapa atau biomasa yang tergolong dalam energy non fosil atau terbarukan.

\subsection{Alat}

Peralatan utama yang akan digunakan dalam penelitian ini adalahsebagai berikut (a) Pengering mekanik multi komoditas, (b) Termometer Alkohol, (c) Hygrometer, (d) Anemometer, (e) Timbangan Analog, (f) Timbangan Pegas, (g) Kanomaks Hot Wire Anemometer, (h) Stopwatch, (i) Moisture balance dan (j) Alat ukur panjang.

\section{Populasi dan Sampel}

Populasi yang dimaksudkan dalam penelitian ini adalah jenis ikan epipelagis dan oseonik. Adapun yang menjadi sampel adalah ikan cakalang (Katsuwonus pelamis L). Ikan cakalang dipilih karena jenis ikan ini merupakan salah satu jenis ikan tangkapan para nelayan dan menjadi sumber protein bagi masyarakat di Provinsi Gorontalo. Sebagai ikan epipelagis dan oseonik ikan cakalang hidup bergerombol serta memiliki warna tubuh berwarna biru baja. Bahan penelitian ini diperoleh dari Tempat Pendaratan Ikan (TPI) Kel. Pohe Kota Gorontalo dengan berat total rata-rata ikan cakalang yakni $30,92 \mathrm{~kg}$ pada setiap pengujian.
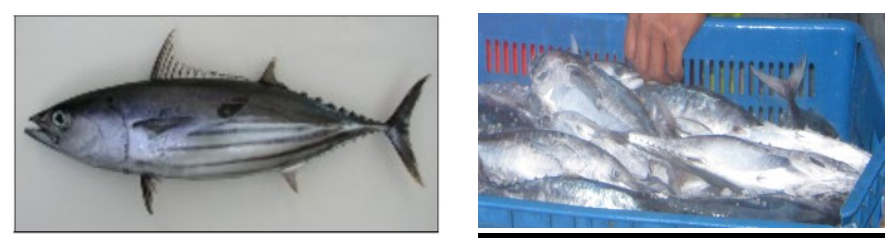

Gambar 2. Ikan Cakalang (Katsuwonus pelamis L)

Pertama-tama, ikan cakalang basah yang akan dikering dalam alat pengering dibelah, dicuci, dibilas dan dibersihkan secara alami untuk menghilangkan darah dan bau amis pada ikan. Organ bagian dalam ikan dipisahkan dari tubuh ikan cakalang sehingga pada proses pengeringan ikan hanya terdiri dari daging dan tulang.

\section{Prosedur Pengambilan Data.}

Urutan pelaksanaan yang dilakukan dalam penelitian ini meliputi :

1). Pastikan semua alat bantu penelitian (instrumen) berfungsi dengan baik.

2). Persiapkan bahan yang akan digunakan dalam percobaan yaitu ikan cakalang yang telah dibersihkan dan ukur kadar air awal ikan dengan menggunakan moisture balance. Diasumsikan, ikan yang akan dikeringkan memiliki kandungan kadar air yang seragam. 
3). Timbang sampel, berikan tanda tertentu pada sampel dan catat data penimbangan. Letakan sampel secara teratur dalam rak kabinet ruang pengeringan.

4). Mempersiapkan alat pengering mekanik multi komoditas tipe udara hembus dan instrumen lain yang akan digunakan dalam percobaan (termometer, timbangan, stopwatch, dan anemometer), nyalakan tempurung kelapa sebagai sumber energi pengeringan dan hidupkan fan serta atur kecepatannya untuk mendapatkan aliran udara yang diinginkan.

5). Catat waktu awal pengujian dan lakukan pengukuran setiap peubah yang akan dianalisis serta lakukan penimbangan bobot ikan setiap 10 menit.

6). Pengujian sistem pengering meliputi : (a) Pengukuran suhu udara, RH udara, kecepatan udara, dan kebutuhan bakar bakar dan (c) Perhitungan laju pengeringan, konsumsi energi spesifik, efisiensitermal, efisiensi pengeringan dan efisiensi total sistem pengering.

\section{Parameter Yang Diukur dan Dianalisis}

Dalam penelitian ini parameter yang diukur meliputi iradiasi surya,kecepatan angin, suhu dan $\mathrm{RH}$ udara lingkungan dan di dalam alat pengering, kecepatan angin, perubahan kadar air produk, dan laju sirkulasi produk (Suwarno dan Prasetyo, 2008; Irfan, 2008).

a. Kadar air

$$
\begin{aligned}
& \text { Kadar air (\% BB) }=\frac{m_{\text {air }}}{m_{\text {air }}+m_{p}} \times 100 \% \\
& \text { Kadar air (\% BK) }=\frac{m_{\text {air }}}{m p} \times 100 \%
\end{aligned}
$$

b. Laju pengeringan

$$
\text { data pengukuran : } \frac{d M}{d t}=\frac{M o-M f}{\Delta t}
$$

c. Energi yang tersedia untuk pengeringan Energi Biomassa (pembakaran)

$$
\mathrm{E} 1=\mathrm{mb} . \mathrm{Nkb}
$$

Energi listrik yang digunakan blower

$\mathrm{E} 2=3,6$ Pk.t

Total energi yang tersedia untuk pengeringan (ET), $\mathrm{kJ}$

$\mathrm{Et}=\mathrm{E} 1+\mathrm{E} 2$

d. Kebutuhan energi untuk pengeringan

Panas yang digunakan untuk menaikkan suhu produk

$$
\begin{aligned}
& \mathrm{Cpb}=0,37+0,034(\mathrm{Mo}) \\
& \mathrm{E} 3=\text { mo.Cpb }(\mathrm{TR}-\mathrm{TB})
\end{aligned}
$$

Panas yang digunakan untuk menguapkan air produk

$$
\text { E4 = Mu.Lh }
$$


Energi total untuk menaikkan suhu dan menguapkan air bahan adalah :

$$
\mathrm{Ep}=\mathrm{E} 3+\mathrm{E} 4
$$

e. Efisiensi pengeringan

pengering $==\frac{E p}{E t} \times 100 \%$

dimana; mbadalah masa biomasa $(\mathrm{kg})$, Nkbadalah nilai kalor biomasa $(\mathrm{kJ} / \mathrm{gr})$, Pk adalah daya kipas (W); t adalah lamanya pengeringan (jam); Mo adalah masa kadar air yang dikandung komoditas (\%); mo adalah masa mula-mula komoditas (kg); TR adalah temperatur pengeringan $\left({ }^{\circ} \mathrm{C}\right)$; TB adalah temperatur komoditas $\left({ }^{\circ} \mathrm{C}\right)$; $\mathrm{Mu}$ adalah masa uap air ( $\mathrm{kguap}_{\text {air }}$ ); Lh adalah panas laten komoditas $(\mathrm{kJ} / \mathrm{kg})$; BB adalah berat basah dan BK adalah berat kering.

\section{Teknik Analisis Data}

Teknik analisis yang digunakan dalam penelitian ini menggunakan persamaanpersamaan matematik seperti yang tercantum pada sub judul (5. Parameter Yang Diukur dan Dianalisis) di atas.

\section{Hasil}

Efisiensi pengeringan dapat diartikan sebagai perbandingan antara energi yang digunakan untuk memindahkan/menguapkan air dari ikan basah dengan menggunakan energi biomasa (tempurung kelapa). Selama pengujian, keadaan cuaca cerah atau normal. Umumnya dalam satu hari pengujian, waktu efektif yang dapat digunakan untuk pengeringan antara dua sampai tiga jam.

Pada saat melakukan pengujian, bobot mula ikan cakalang rata-rata (BMIKRt) adalah 30,92 kg dengan kadar air 69,57 \% dan bobot akhir ikan cakalang kering (BAIKKRt) adalah 14,22 kg dengan kadar air 44,11\%. Menurut Maulana, 2010 bahwa standar kualitas kadar air ikan kering adalah 10,27\%. Nampak bahwa kadar air pada ikan cakalang yang telah dikeringan masih berada diatas standar mutu. Disamping itu, dalam pengujian terjadi penurunan bobot ikan cakalang mencapai 54,0 \%. Adapun perhitungan didasarkan pada data yang telah dicatat dalam tabel pengamatan, perhitungan atau teknik analisis menggunakan persamaan yang telah dicantumkan pada sub judul sebelumnya. Hasil pengukuran dan analisis disajikan dalam bentuk grafik (gambar 3 dan gambar 4) dan tabel 1 dan 2 berikut ini. 


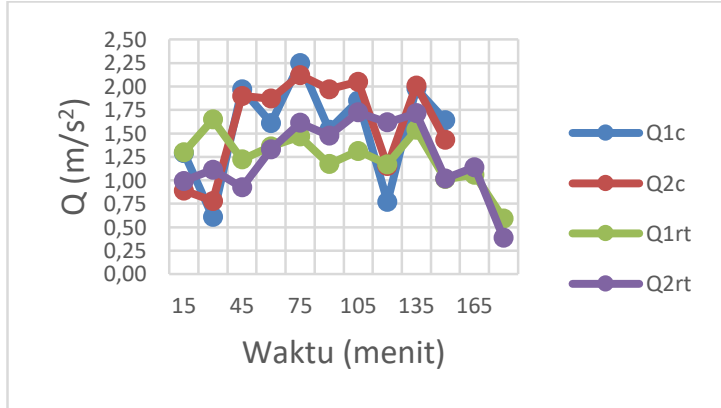

3a. Pengukuran Uji 1 Kecepatan Udara Masuk (Q1) dan Keluar (Q2) kontrol dan Rataan.

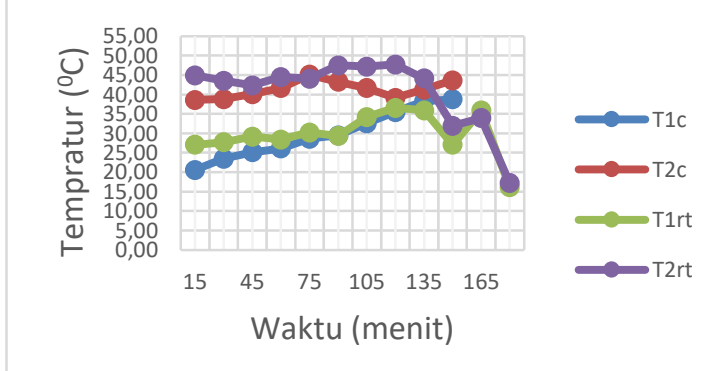

3c. Pengukuran Uji 1 Suhu Udara Masuk (T1), Keluar (T2) Kontrol dan Rataan.

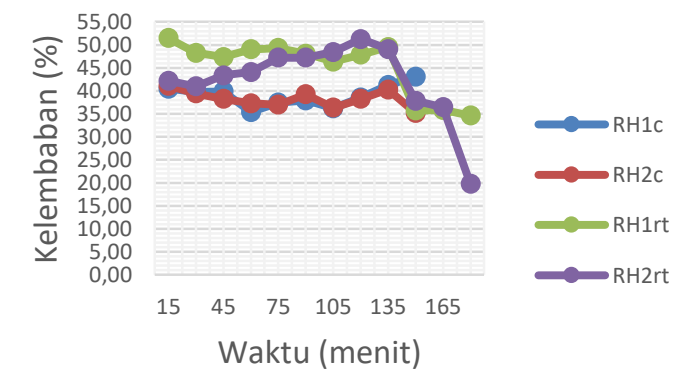

3e. Pengukuran Uji 1 Kelembaban Udara Masuk (RH1) dan Keluar (RH2) Rataan.

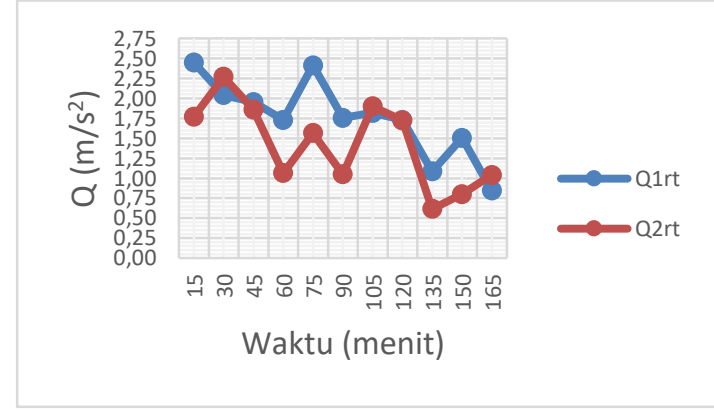

3b. Pengukuran Uji 2 Kecepatan Udara Masuk (Q1) dan Keluar (Q2) Rataan.

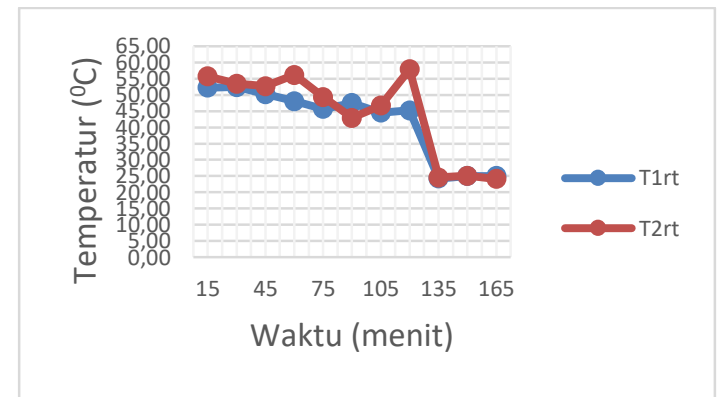

3d. Pengukuran Uji 2 Suhu Udara Masuk (T1) dan Keluar (T2) Rataan.

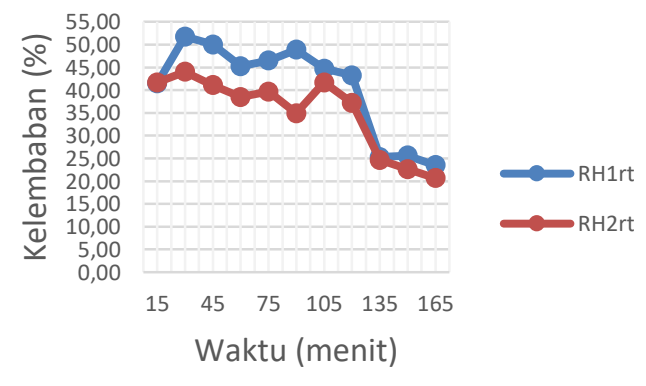

3f. Pengukuran Uji 2 Kelembaban Udara Masuk (RH1) dan Keluar (RH2) Rataan.

Gambar 3. Grafik hasil pengujian 1 dan 2 berdasarkan data pengukuran

Pada Tabel 1 secara ringkas menunjukkan data pengukuran rata-rata dari pengujian yang dilakukan pada alat pengering multi komoditas tipe udara hembus berbahan bakar biomasa. Pengujian dilakukan sebanyak 4 kali dengan 2 kali pengulangan, pada pengujian 1 di hari pertama data yang dihasilkan ambil sebagai kontrol karena pengujiannya dilakukan pada saat ruang pengering masih dalam keadaan kosong atau tanpa benda uji. 


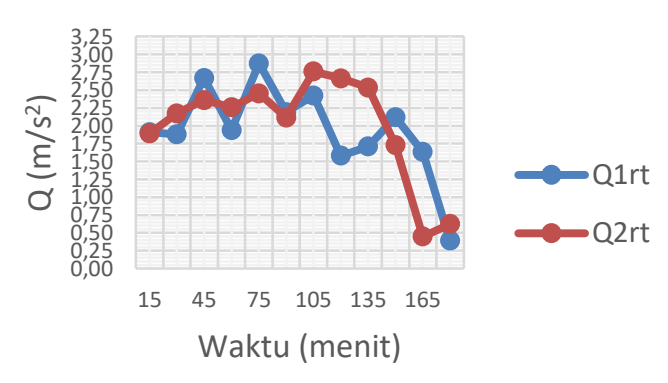

4a. Pengukuran Uji 3 Kecepatan Udara Masuk (Q1) dan Keluar (Q2) Rataan.

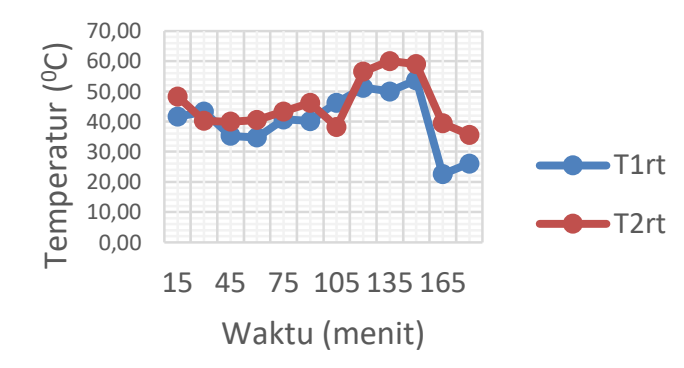

4c. Pengukuran Uji 3 Suhu Udara Masuk (T1), Keluar (T2) Rataan.

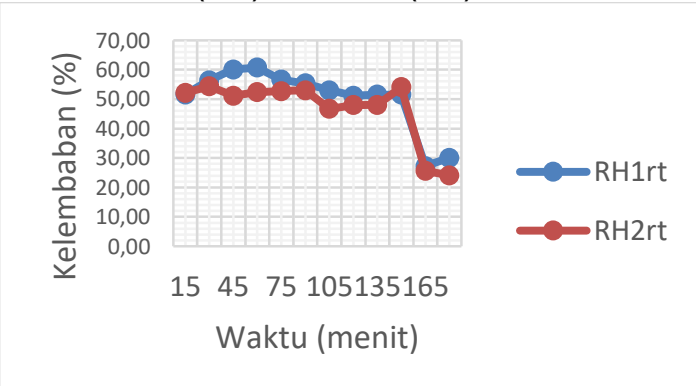

4e. Pengukuran Uji 3 Kelembaban Udara Masuk (RH1) dan Keluar (RH2) Rataan.

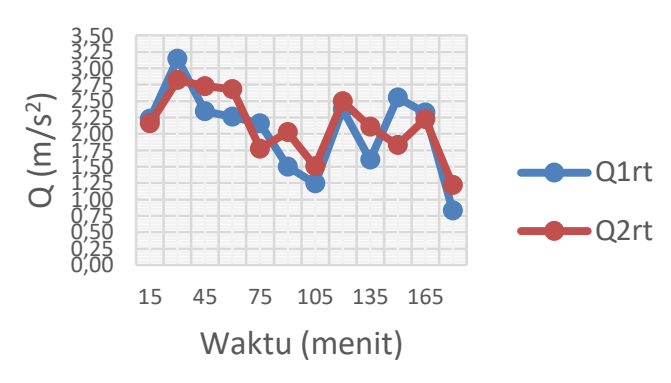

4b. Pengukuran Uji 4 Kecepatan Udara Masuk (Q1) dan Keluar (Q2) Rataan.

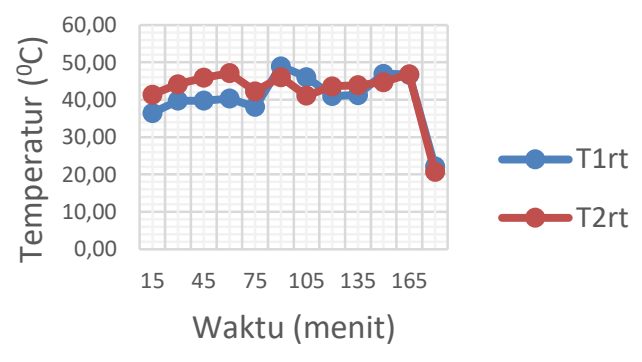

4d. Pengukuran Uji 4 Suhu Udara Masuk (T1) dan Keluar (T2) Rataan.

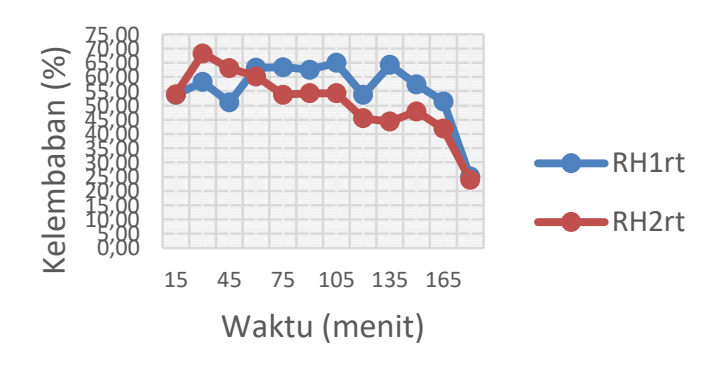

4f. Pengukuran Uji 4 Kelembaban Udara Masuk (RH1) dan Keluar (RH2) Rataan.

Gambar 4. Grafik hasil pengujian 3 dan 4 berdasarkan data pengukuran

Data yang terdapat pada gambar 3 dan 4 yang merupakan grafik hasil pengukuran dan pengujian 1 hingga 4 dengan masing-masing 2 kali pengulangan akan dijadikan dasar untuk menganalisis tingkat efisiensi alat pengering multi komoditas tipe udara hembus berbahan bakar biomasa (APMK tipe UHB). Pada awal setiap pengujian 2, 3 dan 4 selalu diawali dengan Kecepatan udara masuk $\left(Q_{1}\right)$ yang lebih tinggi dari $Q_{2}$ namun berbeda dengan tempratur $\left(\mathrm{T}_{1}\right)$ dan kelembaban $\left(\mathrm{RH}_{1}\right)$ nilainya selalu lebih rendah dari $T_{2}$ dan $\mathrm{RH}_{2}$. Kejadian yang berbeda pada pengujian 1 dimana $T_{1 \mathrm{C}}<\mathrm{T}_{1 \mathrm{rt}}$ dan $T_{1 r t}<T_{2 r t}, R H_{1 c}<R H_{1 r t}, R H_{2 c}$ tetapi $R H_{1 r t}>R H_{2 r t}$. Disamping itu $Q_{1 c}>Q_{2 c}, Q_{1 c}>Q_{2 r t}$ dan $Q_{2}<Q_{1 r t}$ serta $Q_{2}<Q_{2 r t .}$ Secara ringkas hasil analisis disajikan pada Tabel 2. 
Tabel 1. Data Hasil Pengukuran untuk beberapa parameter analisis pengujian APMK Tipe UHB

\begin{tabular}{|c|c|c|c|c|c|c|c|}
\hline \multicolumn{7}{|c|}{ Pengujian 1 } \\
\hline Hari Ke & T1 & RH1 & Q1 & T2 & RH2 & Q2 & Trp \\
\hline 1 & 29,84 & 38,99 & 1,55 & 41,32 & 38,24 & 1,62 & 46,23 \\
\hline 2 & 32,93 & 44,80 & 1,44 & 41,34 & 43,89 & 1,30 & 45,67 \\
\hline 3 & 25,27 & 46,89 & 1,17 & 46,52 & 47,33 & 1,25 & 48,34 \\
\hline \multicolumn{7}{|c|}{ Pengujian 2 } \\
\hline Hari Ke & T1 & RH1 & Q1 & T2 & RH2 & Q2 & Trp \\
\hline 1 & 50,30 & 46,33 & 2,45 & 52,00 & 41,86 & 1,92 & 57,01 \\
\hline 2 & 47,10 & 47,47 & 1,73 & 51,03 & 39,88 & 1,45 & 57,48 \\
\hline \multicolumn{7}{|c|}{ Pengujian 3 } \\
\hline Hari Ke & T1 & RH1 & Q1 & T2 & RH2 & Q2 & Trp \\
\hline 1 & 41,14 & 54,56 & 2,21 & 46,33 & 49,92 & 1,95 & 56,06 \\
\hline 2 & 46,68 & 55,36 & 2,05 & 52,66 & 52,09 & 2,38 & 57,32 \\
\hline \multicolumn{7}{|c|}{ Pengujian 4 } \\
\hline Hari Ke & T1 & RH1 & Q1 & T2 & RH2 & Q2 & Trp \\
\hline 1 & 38,81 & 52,97 & 2,51 & 41,43 & 51,12 & 2,03 & 46,89 \\
\hline 2 & 46,29 & 63,85 & 2,13 & 47,1 & 55,4 & 2,43 & 52,21 \\
\hline
\end{tabular}

Sumber : Hasil Penelitian, 2015 (Diolah)

Berdasarkan tabel 1 dan 2, bahwa penurunan bobot ikan tertinggi terjadi pada pengujian 2 sebesar 20,44 kg, dimana berat ikan pada awal penimbangan yakni 31,79 $\mathrm{kg}$ namun setelah dilakukan proses pengeringan berat ikan setelah melalui penimbangan yakni $11,35 \mathrm{~kg}$. Keempat proses pengujian ini menunjukkan tingkat efisiensi dari APMK Tipe UHB. Secara rerata nilai efisiensi (tertinggi terjadi pada proses pengujian 3 yakni $17,65 \%$ dan nilai efisiensi (terendah terjadi pada proses pengujian 4 yakni $9,14 \%$. Secara keseluruhan tingkat efisiensi dari alat pengering multi komoditas tipe udara hembus berbahan bakar biomasa ini masih tergolong rendah yakni $13,44 \%$. Rendahmya tingkat efisiensi dari APMK Tipe UHB disebabkan beberapa kelemahan dan kelebihannya. Perbandingan beberapa parameter APMK Tipe UHB yang diuji dengan alat pengering tipe circulation drayer (lihat Tabel 3)

Tabel 2. Ringkasan Beberapa Parameter dari hasil analisis pada APMK Tipe UHB

\begin{tabular}{|c|c|c|c|c|c|c|c|c|c|c|}
\hline \multicolumn{10}{|c|}{ Pengujian 1 } \\
\hline $\begin{array}{c}\text { Hari } \\
\text { Ke }\end{array}$ & $\begin{array}{c}\mathrm{K}_{\text {airbsh }}(\%) \\
\left(\begin{array}{c}K_{\text {airkering }} \\
(\%)\end{array}\right.\end{array}$ & $\begin{array}{c}1 \\
\mathrm{Kg} / \mathrm{kg}\end{array}$ & $\begin{array}{c}2 \\
\mathrm{Kg} / \mathrm{kg}\end{array}$ & $\begin{array}{c}\text { mudkering } \\
\mathrm{kg} / \mathrm{s}\end{array}$ & $\mathrm{m}_{\text {ua }} \mathrm{kg}$ & $\begin{array}{c}\mathrm{Mu} \\
\mathrm{kg}\end{array}$ & $\begin{array}{c}\mathrm{E}_{\text {total }} \\
\mathrm{kJ}\end{array}$ & $\begin{array}{c}\mathrm{E}_{\text {produk }} \\
\mathrm{kJ}\end{array}$ & \\
\hline 1 & 71,86 & 39,15 & 1,026 & 1,069 & 0,015 & $\begin{array}{r}6,44 \mathrm{E}- \\
05\end{array}$ & 0,579 & 14258,03 & 1705,356 & 11,96 \\
\hline 2 & 69,26 & 44,37 & 1,125 & 1,134 & 0,009 & $\begin{array}{r}8,44 \mathrm{E}- \\
05\end{array}$ & 0,076 & 14258,03 & 532,817 & 3,73 \\
\hline
\end{tabular}




\begin{tabular}{|c|c|c|c|c|c|c|c|c|c|c|}
\hline \multicolumn{11}{|c|}{ Pengujian 1} \\
\hline 3 & 72,01 & 38,86 & 1,152 & 1,163 & 0,019 & $\begin{array}{r}1,93 \mathrm{E}- \\
05 \\
\end{array}$ & 0,174 & 14258,03 & 807,881 & 5,67 \\
\hline \multicolumn{11}{|c|}{ Pengujian 2} \\
\hline $\begin{array}{c}\text { Hari } \\
\mathrm{Ke}\end{array}$ & Kairbsh & Kairkering & 1 & 2 & mudkering & $\mathrm{m}_{\mathrm{u}}$ & $\mathrm{Mu}$ & $E_{\text {total }}$ & $E_{\text {produk }}$ & \\
\hline 1 & 73,55 & 37,84 & 0,645 & 0,648 & 0,046 & $\begin{array}{r}1,54 \mathrm{E}- \\
04 \\
\end{array}$ & 0,138 & 14258,03 & 1008,327 & 7,07 \\
\hline 2 & 74,89 & 33,53 & 1,345 & 1,345 & 0,018 & $\begin{array}{r}3,62 \mathrm{E}- \\
04 \\
\end{array}$ & 0,326 & 14258,03 & 1435,161 & 10,06 \\
\hline \multicolumn{11}{|c|}{ Pengujian 3} \\
\hline $\begin{array}{c}\text { Hari } \\
\mathrm{Ke}\end{array}$ & Kairbsh & Kairkering & 1 & 2 & mudkering & $\mathrm{mu}_{\mathrm{u}}$ & $\mathrm{Mu}$ & Etotal & Eproduk & \\
\hline 1 & 68,76 & 45,43 & 2,606 & 2,633 & 0,013 & $\begin{array}{r}3,50 \mathrm{E}- \\
04\end{array}$ & 0,315 & 14258,03 & 1335,826 & 9,37 \\
\hline 2 & 66,92 & 49,44 & 0,351 & 0,361 & 0,057 & $\begin{array}{r}5,77 \mathrm{E}- \\
04\end{array}$ & 0,519 & 14258,03 & 1848,954 & 12,96 \\
\hline \multicolumn{11}{|c|}{ Pengujian 4} \\
\hline $\begin{array}{l}\text { Hari } \\
\mathrm{Ke}\end{array}$ & Kairbsh & Kairkering & 1 & 2 & mudkering & $m_{u}$ & $\mathrm{Mu}$ & $E_{\text {total }}$ & Eproduk & \\
\hline 1 & 67,47 & 48,22 & 1,926 & 1,946 & 0,014 & $\begin{array}{r}2,70 \mathrm{E}- \\
04\end{array}$ & 0,246 & 14258,03 & 988,146 & 6,93 \\
\hline 2 & 63,77 & 56,80 & 0,590 & 0,593 & 0,042 & $\begin{array}{r}1,38 \mathrm{E}- \\
04\end{array}$ & 0,124 & 14258,03 & 808,512 & 5,67 \\
\hline
\end{tabular}

Sumber : Hasil Penelitian, 2015 (Diolah)

Berdasarkan Tabel 3 dapat diketahui performance dari alat pengering mekanik multi komoditas tipe udara hembus jika dibandingkan dengan Alat Pengering Tipe Circulation Drayer. Alat pengering mekanik multi komoditas tipe udara hembus memiliki beberapa faktor kelemahan antara lain kapasitas, luasan pengering, ketebalan bahan, kadar air akhir dari komoditas, laju pengeringan, suhu udara pengering dan daya terpasang. Hal ini disebabkan alat ini merupakan disain perdana dan tujuan pembuatannya bukan untuk produksi komersil. Akan tetapi alat pengering mekanik multi komoditas tipe udara hembus memiliki beberapa keunggulan yakni berat muatan perluasan pengering, dan kecepatan udara yang jauh lebih baik dari alat pengering Tipe Circulation Drayer. Disamping itu paling tidak ada dua parameter yang perlu mendapat perhatian yakni kecepatan udara pengering dan lama pengeringan. Kedua parameter ini pada APMK Tipe UHB lebih unggul dari dari alat pengering Tipe Circulation Drayer.

Tabel 3. Parameter Alat Pengering Yang Diuji dan Alat Pengering Pembanding Tipe Circulation Drayer

\begin{tabular}{|c|l|c|c|}
\hline No & \multicolumn{1}{|c|}{ Parameter } & $\begin{array}{c}\text { Alat } \\
\text { Pengering } \\
\text { Diuji }\end{array}$ & $\begin{array}{c}\text { Alat Serupa } \\
\text { Moyer \& Baldwin } \\
(' 99)\end{array}$ \\
\hline 1 & Kapasistas (kg hasil kering/jam) & 146,27 & 295 \\
\hline 2 & Luasan Pengering $\left(\mathrm{m}^{2}\right)$ & 2,45 & 104,05 \\
\hline 3 & Ketebalan Bahan $(\mathrm{cm})$ & 0,5 & 5 \\
\hline
\end{tabular}




\begin{tabular}{|c|l|c|c|}
\hline No & \multicolumn{1}{|c|}{ Parameter } & $\begin{array}{c}\text { Alat } \\
\text { Pengering } \\
\text { Diuji }\end{array}$ & $\begin{array}{c}\text { Alat Serupa } \\
\text { Moyer \& Baldwin } \\
(' 99)\end{array}$ \\
\hline 4 & $\begin{array}{l}\text { Berat muatan perluasan } \\
\text { pengeringan }\end{array}$ & 12,25 & 9,1 \\
\hline 5 & Suhu udara pengering $\left({ }^{\circ} \mathrm{C}\right)$ & $30-53$ & $32-52$ \\
\hline 6 & Kadar air awal $(\%)$ & 74,89 & 75 \\
\hline 7 & Kadar air akhir $(\%)$ & 33,53 & 11,1 \\
\hline 8 & Lama Pengeringan $(\mathrm{jam})$ & 2,5 & 3,2 \\
\hline 9 & Laju Pengeringan $\left(\mathrm{kg} / \mathrm{m}^{2}\right.$.jam) & 1,87 & 9,91 \\
\hline 10 & Kecepatan udara $(\mathrm{m} / \mathrm{det})$ & 3,89 & 1,27 \\
\hline 11 & Sumber panas & Udara panas & Uap/steam \\
\hline 12 & Daya terpasang $(\mathrm{kW})$ & 1,2 & 179 \\
\hline
\end{tabular}

Sumber : Hasil analisis, 2015 (diolah)

\section{Kesimpulan}

Berdasarkan hasil penelitian dan pembahasan maka dapat diambil beberapa simpul, yakni :

1. Performance alat pengeringan ini dapat digolongkan baik bila ditinjau dari proses pengeringannya, alat pengering ini dapat menurunkan kadar air dari suatu produk hingga $33,53 \%$ dengan laju penegringan mencapai $1,87 \mathrm{~kg}$ udara/m².jam serta memiliki tingkat effisiensi $(\eta)$ yang rendah yakni sebesar $13,44 \%$.

2. Ada dua parameter yang unggul dari performance alat pengering mekanik multi komoditas tipe udara hembus jika dibandingkan dengan alat pengering Tipe Circulation Drayer yakni berat muatan perluasan pengering dan kecepatan udara.

\section{Daftar Pustaka}

Al-Kayiem, H.H and Yunus, Md. Y. 2013. Drying Of Empty Fruit Bunches As Wasted Biomass By Hybrid Solar-Thermal Drying Technique. Journal of Mechanical Engineering and Sciences (JMES) Vol. 5: 652-661.

Badan Standar Nasional Indonesia (BSNI). 2009. Standar Nasional Indonesia. Ikan Asap. Badan Standarisasi Indonesia. Jakarta.

BPS, 2017. Propinsi Gorontalo Dalam Angka. Gorontalo.

Ehiem, J.C., S.V. Irtwange and S.E. Obetta. 2009. Design and Development of An Industrial Fruit and Vegetable Dryer. Research Journal of Applied Sciences, Engineering and Technology 1(2): 44-53.

Irfan, Mohamad. 2008. Uji Kinerja Pengering Surya Efek Rumah Kaca Tipe Sirkulasi

Pada Pengeringan Jagung Pipilan. Skripsi tidak diterbitkan. Departemen Teknik Pertanian Fakultas Teknologi Pertanian. IPB. Bogor. 
Junaidi, Bukhari dan Maimuzar. 2011. Pengembangan dan Evaluasi Teknis Alat Pengering Kopra Jenis Tray Dryer. Poli Rekayasa, 7 (1):1-8.

Maulana, I. Muhammad. 2010. Penggunaan Energi Bahan Bakar Untuk Pengeringan Ikan Asin/Keumamah. Mekanika, 8 (2) : 178-182.

Nugroho, Iwan dan Dahuri, Rokhmin. 2012. Pembangunan Wilayah : Prespektif Ekonomi, Sosial dan Lingkungan. Jakarta. LP3ES.

Nindhi and Verma P. 2016. A Review Paper on Solar Greenhouse Dryer. IOSR Journal of Mechanical and Civil Engineering (IOSR-JMCE). AETM 16 : 43-48.

Othman N.F., Yacob M.E., Abdul Rahim A.S., M. Shahwahid O., Hizam H and Ramlan M.F. 2016. Integration of solar dryer technologies in high value herbal crops production for Malaysia: pathway for a sustainable future . International Food Research Journal 23(Suppl): S51 - S55

Silvia, E dan Yuwana., 2012. Kinerja Prototipe Pengering Energi Surya Model YSDUNIB12 Dalam Mengeringkan Singkong. Makalah disajikan dalam Seminar Nasional Fakultas Pertanian Pertanian Universitas Bengkulu, Bengkulu, 12 September 2012.

Sitepu, Tekad., 2012. Pengujian Mesin Pengering Kakao Energi Surya. Jurnal Dinamis, 2(10):23-31.

Sitepu, Tekad dan Purba, G. Indra., 2013. Pengujian Performansi Mesin Pengering Tenaga Surya Dengan Produk Yang Dikeringkan Adalah Cassava Dengan Bentuk Produk Bujur Sangkar. Jurnal e-Dinamis, 7(3) : 117-125.

Suwarno dan Prasetyo, T. 2008. Pembuatan Alat Pengering Ikan Teri Hitam Dengan Sistem Udara Hembus Berkapasistas $12 \mathrm{~kg}$ Ikan Basah. Jurnal Orbit, 4(3): 436-441.

Witono, J. Retti, Miryanti Y.I.P, Arry dan Yuniarti, Lia. 2013. Studi Kinetika Dehidrasi Osmotik Pada Ikan Teri Dalam Larutan Biner Dan Terner. Laporan Penelitian. LP2M Unika Parahyangan. Bandung.

Wolok, Eduard dan Wunarlan, Irwan. 2012. Perancangan dan Analisis Performance Alat Pengering Mekanik Tipe Udara Hembus. UNG Repositori. Gorontalo.

Yani, Endri., Abdurrachim dan Pratoto, Adjar. 2009. Analisis Efisiensi Pengeringan Ikan Nila Pada Pengering Surya Aktif Tidak Langsung. Jurnal Teknika, 2(31) : 26-33. 